\title{
RESOURCE USE EFFICIENCY OF GROUNDNUT PRODUCTION IN RINGIM LOCAL GOVERNMENT AREA OF JIGAWA STATE, NIGERIA ${ }^{1} \mathrm{M}$. Zekeri. and 21 . Tijjani. \\ 1 Department of Agricultural Economics and Extension, Bayero University Kano, Nigeria \\ 2 Department of Crop Protection, Bayero University, Kano Nigeria. \\ Email: muniratzak4u@gmail.com
}

\begin{abstract}
The study was conducted to measure the resource use efficiency in groundnut production in Ringim Local Government Area, Jigawa State. A stratified sampling technique was employed to select 58 respondents. The tool for collection of primary data was structured questionnaires. The data collected were analysed using production function and efficiency model. The linear production function analysis showed that the coefficient of multiple determinantion- $R^{2}$ of the production was $76.5 \%$ while the F-value was 27.6. The analysis revealed that among the variables, seed, hired labour and pesticide use in the groundnut production were significant $(p<0.1)$ while fertilizer, family labour and farm size were not significant. The returns to scale was 1.77. For resource use efficiency, seeds, family labour and hired labour were under-utilized, while fertilizers and pesticides were over-utilized. It is concluded that in-spite of their small farm size, there is still opportunity to increase their production to attain optimal economic efficiency. The study recommends that farmers should be encouraged to use more variable inputs to get more profit and youth should be encouraged to participate in groundnut production.

Keywords: Groundnut Production, Production Function,- Regression Model and Resource Use Efficiency.
\end{abstract}

\section{INTRODUCTION}

Groundnut (Arachis hypogaea L.) is the $6^{\text {th }}$ most important oil seed crop in the world. It contains $48-50 \%$ oil, $26-28 \%$ protein and $11-27 \%$ carbohydrate, minerals and vitamin (Mukhtar, 2009). Groundnut is grown on 26.4 million hectare worldwide, with a total production of 37.1 million metric tons and an average productivity of 1.4 metric tons /ha. Developing countries constitute $97 \%$ of the global area and $94 \%$ of the global production of this crop (FAO, 2011). The production of groundnut is concentrated in Asia and Africa, where the crop is grown mostly by smallholder farmers under rain-fed conditions with limited inputs). Nigeria was the third highest producer of groundnut in the world after China and India with a production of 16,114,231, 6,933,000 and $2,962,760$ tons respectively in 2011. In Nigeria, the crop is presently grown throughout the country with the exception of the riverine and swampy areas. Groundnut occupies between 1.5 and 2 million ha of land of the country's land (Olurunju, 2000). Groundnut is either cultivated sole or in mixtures with other crops like maize, sorghum, millet or cassava. Fifty five percent of the groundnuts produced in Nigeria are in mixtures (Anonymous, 2004)). In Nigeria, the leading producing states include Niger, Kano, Jigawa, Zamfara, Kebbi, Sokoto, Katsina, Kaduna, Adamawa, Yobe, Borno, Taraba, Plateau, Nasarawa, Bauchi, and Gombe States (NAERL, 2011). 
In the Northern part of Nigeria, apart from being consumed whole, edible groundnuts are processed into or included as an ingredient in a wide range of other products which includes groundnut paste which is fried to obtain groundnut cake (kuli kuli), salted groundnut (gyada mai gishiri), a gruel or porridge made with millet and groundnut (kunun gyada), groundnut candy (kantun gyada) and groundnut soup ( miyar gyada).The shells are used for fuel by some local oil factories or they are sometimes spread on the field as a soil amendment. They could also be used as bulk in livestock rations or in making chipboard for use in joinery (Mukhtar, 2009). Groundnut pod yields from farmers' field are low, averaging about $800 \mathrm{~kg}$ ha-1, less than onethird the potential yield of $3000 \mathrm{~kg}$ ha-1. This large gap between actual and potential yields is due to several factors, including non-availability of seeds of improved varieties for a particular ecology, poor soil fertility, inappropriate crop management practices, pests and diseases (Ahmed et al., 2010).

Groundnut diseases are caused by fungi, bacteria, viruses, nematodes and mycoplasma (Craufurd et al., 2006). The disease wiped more than 750,000 ha of groundnut field which brought a tremendous loss to both farmers and marchants. Second is the coincidence of oil boom in Nigeria about the same time (Ntare et al., 2005). The loss from the groundnut and availability of oil money transformed the groundnut merchants to government contractors. Government on its part equally shifted its attention from agriculture as a whole to the oil industry. However, one of the major problems of groundnut production is low yield. This is attributed to poor production techniques used by peasant farmers, and inadequate supplies of inputs such as improved seed varieties, fertilizer, chemicals and machinery. Inter cropping is also to be considered as another factor contributing to groundnut low yielding. This is as a result of small plant population of groundnut crop and the initial shading imposed by other crops such as sorghum and guinea corn varieties (Ntare et al., 2005). The low output realized by smallholder farmers is an indication that resources needed in the production of crops are not at optimal levels (Nweze, 2002; Panwal et al., 2006; Adinya et al, 2008). There is need to increase crop production using resources efficiently that allows sustainable levels of food production (Owa et al., 2006). As a result, there is need to reverse the foregoing scenario with a view to improving the productivity and efficiency of resource use among groundnut farmers through the investigation of the nature of productivity and efficiency in their production (Taru et al., 2008)

This paper therefore seeks to examine the major determinants in groundnut production and the resource use efficiency of groundnut production in Ringim Local Government of Jigawa State

\section{Study Area}

\section{MATERIAL AND METHODS}

The study was conducted in Ringim Local Government Area (LGA) of Jigawa State. The LGA has the wards and the main reason for its selection was that it has high concentration of producers of groundnut,. Ringim L.G.A was created in 1976 and it lies between latitude 110-130 north and longitude $8^{\circ}-10.15^{\circ}$ east. It is bounded to the east by Taura LGA, to the south by Dutse LGA and to the north by Garki LGA. The main ethnic groups in the area are Hausa and Fulani. The area is 
an educational and commercial city. The educated population are gainfully employed in some organization while the fairly literate depends on trading during off season. Agricultural activities are the main occupation in the study area, which accounted for about $70 \%$ and other activities accounted for the remaining $30 \%$ (JSG, 2006). Examples of crops grown in the LGA are millet, sorghum, groundnut, cowpea, cassava, maize among others while livestock usually kept include cattle, sheep, goat, chicken and duck.

\section{Sampling Techniques and Sample Size}

Among the ten political wards in Ringim LGA, only three were preponderantly engaged in groundnut production for commercial purpose on small and medium scale production while the remaining seven wards produce at subsistence level. A pre-survey was conducted in which an estimated total of $\mathbf{2 8 6}$ groundnut farmers were identified from the three political wards using the village head as key informant and guide; hence 58 farmers were selected using stratified sampling, where 20, 20 and 18 respondents were selected from Karshi, Beguwa and the Kafin Babushe respectively. The sampling was designed so that designated number of persons is chosen from each stratum in order to get a well distributed representative (Gupta, 2002).

\section{Data collection and analytical tools}

Copies of structured questionnaires were administered to the sampled farmers by the researcher, assisted by a trained enumerator from the state's ADP for data collection.Proper and adequate data analysis is essential for reliable conclusion for any research work. The tool employed in analysing the data was production function model.

\section{Production function model:}

Production function has been defined by Olukosi et al. (2007) as the physical relationship between inputs on one hand and output on the other in any production processes.

Multiple regression:- Regression model is a casual relationship between two or more independent variables and a dependent variable (Gupta, 2002). For the purpose of this study, the regression models specified were linear, semi log and cob Douglas forms. The Linear Production Function (LPF) assumes a linear relationship between the inputs and outputs as well as constant marginal productivities of the resources used. It takes the following;

$$
Y=A_{0}+A_{1} X_{1}+A_{2} X_{2}+A_{3} X_{3}+A_{4} X_{4}+A_{5} X_{5}+A_{6} X_{6}+U
$$

Where:

$\mathrm{Y} \quad=\quad$ Total output of groundnut (in bags);

$X_{1}=$ Seeds $(\mathrm{kg})$;

$X_{2}=$ Fertilizer $(\mathrm{kg})$;

$\mathrm{X}_{3}=\quad$ Family labour (man days);

$X_{4}=\quad$ Hired labour (man days);

$X_{5}=$ Pesticide (litre);

$\mathrm{X}_{6}=$ Farm size (Hectares);

$A_{1}-A_{6}=$ Regression coefficients of the inputs;

$\mathrm{A}_{0}=$ Constant

$\mathrm{U}=$ Error term. 
In determining the determinants in groundnut production in the study area, the analytical procedure employed was regression analysis. Three forms (such as linear, semi and double log) were tried and the equation with the best fit based on $\mathrm{R}^{2}$ and significance of the coefficients and a priori expectation was chosen and consideration of the expectation of econometric and statistical criteria including sign and magnitude of coefficients are included before final selection and the most suitable equation.

\section{Resource Use Efficiency}

Note that efficient production is represented by an index value of 1.0 , while lower values indicate a greater degree of inefficiency.

The following ratio based on the estimated regression coefficients was used to estimate the relative efficiency of resource use ( $r$ )

\section{r=MVP/MFC------------- (2) Decision Rule}

If $r=1$, resource is efficiently utilized;

$r>1$, resource is underutilized;

$r<1$, resource is over utilized.

Economic optimum takes place where MVP = MFC.

If $r$ is not equal to 1, it suggests that resources are not efficiently utilized. Adjustment could therefore, be made in the quantity of inputs used and costs in production process to restore $r=1$.

The values of MVP and MFC were estimated as follows:

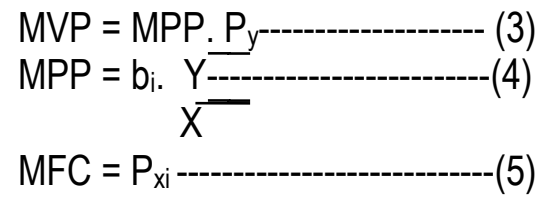

Where:

$r=$ Efficiency Ratio;

MVP = Marginal Value Product;

MPP = Marginal Value Product;

MFC = Marginal Factor Cost, $\mathrm{P}_{\mathrm{xi}}$ (unit price of input $\mathrm{x}_{\mathrm{i}}$ );

$\bar{Y}=$ Arithmetic Mean Value of Output;

$\bar{X}=$ Arithmetic mean value of input considered;

$P_{y}=$ Unit Price of Output;

$P_{x}=$ Unit price of Input

\section{RESULTS AND DISCUSSION}

The best model was linear. This result is presented in Table 1. 
Table 1:-Linear Multiple regression analysis of the variable inputs of groundnut production.

\begin{tabular}{llll}
\hline Explanatory variables & Regression coefficients & Standard errors & T-values \\
\hline Constant term $(\mathrm{a})$ & $91.158^{*+*}$ & 17.125 & 3.668 \\
Seed $\left(\mathrm{X}_{1}\right)$ & $0.564^{* *+*}$ & 0.16 & 3.33 \\
Fertilizer $\left(\mathrm{X}_{2}\right)$ & $-0.57^{\mathrm{NS}}$ & -0.63 & -0.588 \\
Family labour $\left(\mathrm{X}_{3}\right)$ & $0.86^{\mathrm{NS}}$ & 0.17 & 0.697 \\
Hired labour $\left(\mathrm{X}_{4}\right)$ & $0.34^{*}$ & 0.128 & 1.914 \\
Pesticide $\left(\mathrm{X}_{5}\right)$ & $0.159^{*}$ & 0.0005 & 2.26 \\
Farm size $\left(\mathrm{X}_{6}\right)$ & $0.42^{\mathrm{NS}}$ & 0.84 & 0.437 \\
$\mathrm{R}^{2}$ & 0.765 & & \\
F-value & $27.6^{*+*}$ & & \\
$\mathrm{~N}$ & 58 & & \\
\hline
\end{tabular}

Source: Survey data, 2008.

Key:

$*=5 \%$ probability level

$* *=1 \%$ probability level

$* * *=0.1 \%$ probability level

NS $=$ Not significant $(P<0.05)$

The regression equation is given as:

$Y=91.158+0.564 X_{1}(0.16)+0.57 X_{2}(0.63)+0.86 X_{3}(0.17)+0.34 X_{4}(0.128)$

$+0.159 X_{5}(0.0005)+0.42 X_{6}(0.84)$

The result indicates that the coefficient of multiple determinations, $\mathrm{R}^{2}$ is $76.5 \%$. This implies that $76.5 \%$ of the total variation in the output of groundnut was accounted for the explanatory variables included in the model, while the remaining $23.5 \%$ variation of the dependent variable was accounted for by disturbance term. This finding is in line with Taru et al. (2008) that has $\mathrm{R}^{2}$ of $78.40 \%$ in his study of economic Efficiency of Resource Use in Groundnut Production in Adamawa State of Nigeria. The F-value (27.6) measures the joint significance of all the explanatory variables of the model which is not significant at $5 \%$ level of probability. The t-values observed in able 1 were used to test the significance of each explanatory variable in the model. The regression analysis shows that the coefficient of seeds $\left(X_{1}\right)$ is 0.56 and is significant at $0.1 \%$ level of probability. This implies that $1 \%$ increase in seeds input increases the net output by $0.6 \%$. Also The positive value of seed coefficient means higher seed rate in $\mathrm{kg} / \mathrm{ha}$ implies greater that number of crops stands per hectare and consequently higher yield, except where there is overcrowding leading to competition for nutrients and low yields. This result agrees with the study of Taru et al. (2008) in which the coefficient of seed input was found to be positive and significant at $1 \%$. The coefficient of the fertilizer $\left(X_{2}\right)$ is $-0.57 \%$ and not significant at $5 \%$ level of probability. The negative sign implies that the quantity of fertilizer applied was not directly related to the output while the statistical insignificance of the coefficient implies that fertilizer was not a determinant of output in groundnut production. This is also in line with Taru et al., (2008) that reported the statistical insignificance of fertilizer coefficient. The coefficient of family labour $\left(X_{3}\right)$ is $0.86 \%$ but not significant at $5 \%$ level of probability with implication that family labour contributes positively to the output, though the effect is not real. The coefficient of hired labour $\left(X_{4}\right)$ is $0.34 \%$ 
and significant at $5 \%$ level of probability. With implication that increase in hired labour by $5 \%$ increases the net output by $34 \%$. The coefficient of pesticide $\left(X_{5}\right)$ is $0.159 \%$ and is significant at $5 \%$ level of probability. This implies that $5 \%$ increase in pesticide increases the net output by only $16 \%$. Moreover, the coefficient of farm size $\left(X_{6}\right)$ is $0.42 \%$, not significant at $5 \%$ level of probability. This implies that farm size contributes positively to the output.

Returnss to scale:

Returnss to scale measures the proportionate change in output, if all the inputs are changed simultaneously by one percent. It represents the sum of all the regression coefficients with respect to all the inputs.

Table 2:-Returns to scale for the producers of groundnut

\begin{tabular}{llllllll}
\hline Variables & Seeds & Fertilizer & $\begin{array}{l}\text { Family } \\
\text { labour }\end{array}$ & $\begin{array}{l}\text { Hired } \\
\text { labour }\end{array}$ & Pesticide & Farm size & $\begin{array}{l}\text { Returns to } \\
\text { scale }\end{array}$ \\
\hline Coefficients & 0.56 & -0.57 & 0.86 & 0.34 & 0.159 & 0.42 & 1.77 \\
\hline
\end{tabular}

Source: Survey data, 2008.

The returnss to scale is 1.77 which was the sum of elasticities as shown in Table 2 . This value being greater than unity (1) means that the farmers are operating at the region of increasing returnss to scale. Increasing returnss portrays a case whereby an additional unit of input results in a larger increase in product than the preceding unit. This suggests that groundnut famers in the area can increase their output by increasing the use of some of these key resources. This requires re-allocation of existing resources. This implies that if all explanatory variables are simultaneously increased by one percent, the total physical output of the groundnut will increase by $1.77 \%$. This implies that production was in the irrational zone of production (stage 1) and that the percentage change in the variable input. That is factor input were not efficiently allocated and utilized while output was optimally produced. This agrees with the work of Taru et al. (2008) that reported an increasing returns to scale of 1.124 of groundnut production in Adamawa State. Also, the result tallies with Vincent et al., (2012) that also reported an increasing returns to scale of 1.87 of groundnut farmers in Kasungu district, Malawi.

\section{Resources use efficiency}

The result of the resources use efficiency is presented in Table 3.

Table 3:-.Marginal Value Products (MVP) and Marginal Factor Cost (MFC) of the variable inputs

\begin{tabular}{llll}
\hline Variable inputs & MVP $(\mathbf{N})$ & MFC $(\mathbf{N})$ & MVP/MFC \\
\hline Seeds $(\mathrm{Kg})$ & 854.39 & 142.8 & 5.93 \\
Fertilizer (kg) & -546 & 81 & -6.74 \\
Family labour (man-days) & 1817.46 & 600 & 3.0 \\
Hired labour (man-days) & 1118.2 & 600 & 1.86 \\
Pesticide (liter) & 112.01 & 200 & 0.56 \\
\hline
\end{tabular}

Source: Field Survey, 2008.

Table 3 shows that seed has a MVP of $\$ 854.39$ which is greater than its unit acquisition cost ( 142.8) and has MVP to MFC ratio of 5.98. This implies that increasing seeds by one kilogram 
would increase TCP by $\$ 142.8$ and revenue by $\$ 854.39$. Therefore, farmers can increase their profit by increasing seed input. Under utilization of seed could be as a result of high cost of seed. As this input is expensive, most farmers do not think about its optimal use (Vincent et al., 2012).

Fertilizer on its own has a MVP of -546 and MFC of N81 with MVP/MFC ratio of -6.74 . This implies that increasing fertilizer by one kilogram leads to the decrease in revenue by N546. From this result, it is advisable that farmers should cut down the use of fertilizer to reduce TCP and improve profit.

Table 3 also reveals that the MVP of family labour is $\mathrm{N} 1817.46$ and MFC of N600 with MVP/MFC ratio of 3.0; this implies that increasing family labour by one man-day increases the revenue by A1, 817.46. Hence farmers should consider increase more family labour to get more profit.

The MVP of hired labour is $\$ 1118.2$, MFC is $\$ 600$ and MVP/MFC ratio is 8.86 as shown in Table 3. This implies that increase in hired labour by one man-day increases TCP by N600 and revenue increases by $\mathbf{1 1 1 8 2}$. Hence farmers can increase their profit by increasing hired labour.

Moreover, the MVP of pesticide is $\$ 112.01, \mathrm{MFC}$ is $\mathrm{N} 200$ and MVP/MFC ratio is 0.56 . This means additional one liter of pesticide the TCP would increase by $\$ 200$ and revenue would decreases by $\$ 112.01$. Therefore, farmers should cut down/reduce the use of pesticide to reduce the TCP and increases the profit.

Table 3 also reveals that the ratios of the MVP to the MFC were greater than unity (1) for all the variable inputs except fertilizer and pesticide. This implies that seed, family labour and hired labour were under-utilized, hence increasing their rate of use will increase output and profit level while fertilizer and pesticide were over-utilized (less than one) indicating that the inputs were excessively used or over utilized hence decreasing quantity of the inputs use will increase output and profit level. This confirms that resources are not efficiently utilized. These findings also tallies with that of Taru et al. (2008) that reported that labour and seed were underutilized while fertilizer and agrochemical were overutilized in groundnut output in Adamawa State.

\section{CONCLUSION AND RECOMMENDATIONS}

In spite of their small farm size, there is still opportunity for the producers of groundnut to increase their production to attain optimal economic efficiency, because of the under-utilization of key resources included in the model. The implication of the study is that resource efficiency in groundnut production in the area could be increased through better use of improved seeds, family labour and hired labour.

Based on the result obtained, the study recommended the following measures;

I. Improved inputs such as seeds should be made available to farmers at affordable price by the stakeholders to the production of groundnut in the study area.

II. Farmers should be encouraged to effectively utilize the resources use in groundnut production to get more profit through extension services. 


\section{REFERENCES}

Adinya, I. B., Kuye, O. O., Awoke, M. U., Ajayi, S., Ele, I. E., Ogbonna, K. I.,Ekpet. S. O. and Agba, A. O. (2008). Production Function Analysis of Cassava Sole Cropping system in Akwa ibom state. Nigeria. Global Journal Pure and Applied Science. 14(1):13-17.

Ahmed, S., Rafay, A., Singh, R.. K. and Verma, U.K. (2000). Response of groundnut varieties to spacing. Indian Journal of Agronomy, 31(3):248-251

Anonymous, (2004). Raw Materials Research and Development Councils Survey of Agro Raw Materials: Groundnut 96

Craufurd. P. W., Prasad, P. V. V. , Taheri, A. and Waliyar, F. (2006). Drought pod yield, preharvest Aspergillus infection and aflatoxin contamination on peanut in Niger. Field Crops Research 98: 20-29.

Food and Agricultural Organization, (2011). Report- FAOSTAT Production Year Book

Gupta, S.P. (2002): Statistical methods. Gultan Chand and sons educational publishers, New Delhi. Thirty first edition, $75-76$.

Jigawa State Government (2006). National Population Commission, Census Report 2006. 30-35

Olorunju, P. E. (2000). Evaluation of production, multiplication and distribution systems of improved groundnut germplasm in Nigeria. A TCP/RAF/7 823 (A) Report. 4

Olukosi, J. O. and Ogungbile, A.O. (2007). Introduction to Agricultural Production Economics; Principles and application. $3^{\text {rd }}$ Edition Agitab publishers limited. Zaria, Nigeria. 112

Mukhtar, A. A. (2009). Performance of three groundnut (Arachis hypogaea L.) varieties as affected by basin size and plant population at Kadawa. Ph.D. Dissertation Submitted to Postgraduate School, Ahmadu Bello University, Zaria 173

NAERL, (2011). Agricultural survey for 2011 wet seasons National Agricultural Extension Research and Liaisons Service

Ndjeunga, J., Ntare B. R., Ramouch, M., Masters, E. and Waliyar, F. (2005). Market prospects for Groundnut in West Africa (Eng/Fr). CFC Technical Paper No. 39 PO Box 74656, 1070 BR Amsterdam. The Netherlands: Common Fund for Commodities; and Patancheru, India: International Crops Research Institute for the Semi-Arid Tropics. 252

Nweze, N. J. (2002). Agricultural Production Economics: An Introductory Text AP Express Publishers Limited, Nigeria

Owa, O., Udom, G. N., Ampitan ,T. A. and. Joshua, V. I. (2006). The Contribution of Agro-forestry Practices to Crop Production (A Review). A paper Presented at $20^{\text {th }}$ Annual National Conference of Farm Management Association of Nigeria held at Forestry Research Institute of Nigeria, Federal College of Forestry Bauchi, Plateau State .18 ${ }^{\text {th }}-21{ }^{\text {th }}$ September, 2006. 550-561. 
Zekeri \& Tijjani, 2013

Panwal, E. F., Nweze, J. N. and Banwar, J. (2006). Resource-Use and Productivity Among Rain-fed and Irrigated Irishi Potato producers in Plateau State Nigeria. A paper Presented at $20^{\text {th }}$ Annual National Conference of Farm Management Association of Nigeria held at Forestry Research Institute of Nigeria, Federal College of Forestry Bauchi, Plateau State. $18^{\text {th }}-21^{\text {th }}$ September, 2006. 25-29.

Taru, V. B., Kyagya, I. Z., Mshelia, S. I. and Adebayo, E. F.(2008). Economic Efficiency of Resource Use in Groundnut Production in Adamawa State of Nigeria. World Journal of Agricultural Sciences 4 (S): 896-900. ISSN 1817-3047 @ IDOSI Publications.

Vincent, K. and Maganga, A. (2012). Economic Analysis of Groundnut Production in Kasungu District, Malawi: A production Economics Approach. Munich Personal RePEc Archive MPRA Paper No. 41593, posted 28. September 2012 11:04 UTC. Online at http://mpra.ub.unimuenchen.de/41593/ 